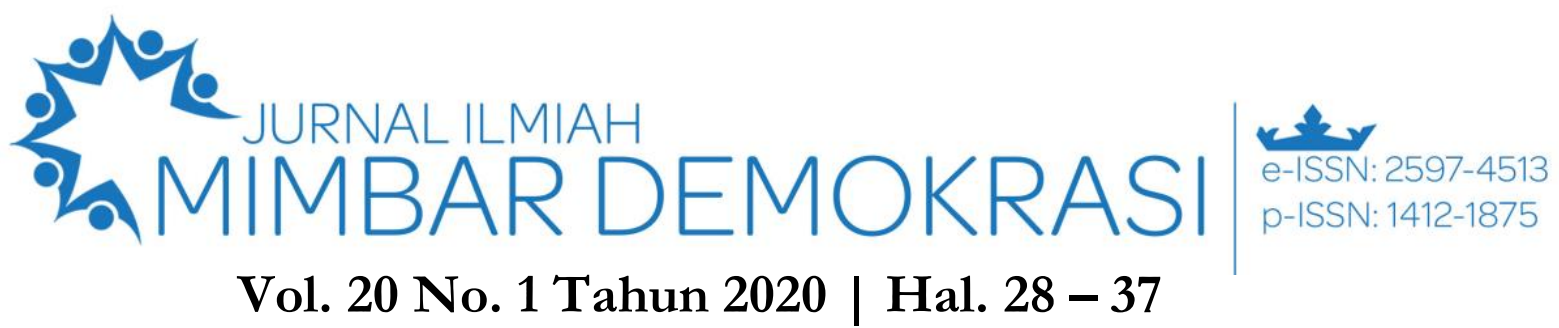

\title{
Upaya pembentukan karakter kepemimpinan lintas budaya dalam membangun kemampuan resolusi konflik generasi milennial
}

(Studi kasus pada mahasiswa Universitas Buana Perjuangan Karawang)

\author{
Aris Riswandi Sanusi a, 1*, Bunyamin Maftuh b, 2, Elly Malihah c, 3 \\ a Universitas Pendidikan Indonesia, Indonesia \\ ${ }^{1}$ arissanusi@upi.edu*; ${ }^{2}$ bunyaminmaftuh@upi.edu; ${ }^{3}$ ellyms@upi.edu \\ *korespondensi penulis
}

$\overline{\text { Informasi artikel }}$

Diterima:

18 Juni 2020

Disetujui:

3 Oktober 2020

Kata kunci:

Kepemimpinan Lintas

Budaya

Resolusi Konflik

\begin{abstract}
ABSTRAK
Konflik merupakan suatu keniscayaan dalam kehidupan masyarakat sehingga menuntut mahasiswa untuk memiliki karakter kepemimpinan lintas budaya dan kemampuan resolusi konflik sebagai upaya mengelola konflik menjadi suatu kekuatan bangsa. Penelitian ini bertujuan untuk mengetahui upaya yang dilakukan Universitas Buana Perjuangan dalam membentuk kemampuan resolusi konflik mahasiswa. Penelitian ini dilakukan dengan menggunakan pendekatan kualitatif dan metode deskriptif dengan pengumpulan data melalui wawancara pada dosen dan mahasiswa, observasi, dan studi literatur. Hasil yang ditemukan yaitu upaya yang dilakukan Universitas Buana Perjuangakan Karawang dalam membentuk karakter kepemimpinan lintas budaya dan kemampuan resolusi konflik mahasiswa dilakukan dengan cara pelembagaan melalui orientasi pegawai dan mahasiswa, pembentukan satuan pengawas internal dan lembaga penyelesaian konflik, serta upaya edukatif yang dilakukan melalui kolaborasi pelatihan kepemimpinan, Pendidikan Kewarganegaraan, dan Jatidiri Bangsa. Melalui upaya-upaya tersebut tercipta suasana kondusif yang tercermin dalam interaksi akademik yang tertib dan solutif.
\end{abstract}

\begin{abstract}
Conflict is a necessity in people's lives so it requires students to have cross-cultural leadership character and conflict resolution ability as an effort to manage conflict into a nation's strength. This study aims to to find out the efforts made by the Buana Perjuangan University in shaping student conflict resolution abilities. This research was conducted using a qualitative approach and descriptive method by collecting data through interviews with lecturers and students, observation, and literature studies. The results found were the efforts made by the Buana Perjuangan University in forming cross-cultural leadership character and the ability of student conflict resolution carried out by institutionalization through employee and student orientation, the formation of internal supervisory units and conflict resolution institutions, as well as educational efforts undertaken through collaborative leadership training, Citizenship Education, and National Identity. The impact creates a conducive atmosphere which is reflected in orderly and solution academic interactions.
\end{abstract}

Copyright $\odot 2020$ (Aris Riswandi Sanusi, Bunyamin Maftuh \& Elly Malihah). All Right Reserved

How to Cite: Sanusi, A. R., Maftuh, B. \& Malihah, E. (2020). Upaya pembentukan karakter kepemimpinan lintas budaya dalam membangun kemampuan resolusi konflik generasi milenial. Jurnal Ilmiah Mimbar Demokrasi, 20(1), 28-37. DOI: 10.21009/jimd.v20i1.15661

This work is licensed under a Creative Commons Attribution-ShareAlike 4.0 International License. Allows readers to read, download, copy, distribute, print, search, or link to the full texts of its articles and allow readers to use them for any other lawful purpose. The journal holds the copyright.

\begin{tabular}{ll}
\hline Pendahuluan & dihadapi seluruh masyarakat dunia. Arus \\
Globalisasi dewasa ini menjadi sebuah & informasi dan komunikasi yang berkembang \\
kemajuan sekaligus tantangan yang harus & pesat tidak terkecuali berdampak pada
\end{tabular}




\section{Vol. 20 No. 1 Tahun 2020 | Hal. 28 - 37}

pergeseran nilai. Pergeseran nilai tersebut disebabkan oleh tekanan yang diberikan globalisasi dalam seluruh aspek kehidupan kebangsaan, seperti ekonomi, sosial budaya, hukum, dan politik. Kekuatan utama globalisasi, yang meliputi saling ketergantungan ekonomi, semakin pentingnya organisasi politik dan ekonomi internasional, dan peningkatan migrasi yang cepat adalah kenyataan yang telah menyebabkan komunitas akademik di bidang kajian kewarganegaran menyerukan interpretasi kewarganegaraan yang lebih global (Banks, 2004; Barbule \& Torres, 2000; castle, 2004, Heater, 2000, Morais \& Ogden, 2011, Oxfam, 2006, Rapoport, 2010). Perkembangan globalisasi yang begitu pesat ini membuka mata manusia untuk melihat segala bentuk perbedaan yang ada di dunia ini baik perbedaan ras, agama, etnis, budaya, dan gender. Hal ini serta merta membawa dampak pada pergeseran nilai manusia yang membeda-bedakan dengan manusia lainnya. Perbedaan-perbedaan ini seyogyanya tidak bisa dikatakan hierarkis atau dengan kata lain tidak bisa diklasifikasikan secara vertikal. Mengingat perbedaan inilah yang menopang kehidupan manusia di dunia.

Tak terlepas juga bagi Indonesia sebagai negara berkembang menjadi salah satu tujuan dari dampak yang dihasilkan oleh globalisasi. Globalisasi dewasa ini menjadi sebuah tuntutan yang harus dihadapi seluruh warga negara dunia. Pesatnya arus informasi dan komunikasi berdampak pada pergeseran peran warga negara yang menuntut untuk semakin dewasa dalam menyikapinya. Pergeseran peran warga negara disebabkan oleh tekanan yang diberikan globalisasi dalam seluruh aspek kehidupan kebangsaan, seperti ekonomi, sosial budaya, hukum, dan politik. Terlebih, Indonesia merupakan suatu bangsa yang memiliki karakteristik masyarakat majemuk dibangun atas keragamana suku bangsa, ras, agama, termasuk sistem sosial budaya. Layaknya diungkapkan Wilodati (2010, hlm.157) bahwa "Bangsa Indonesia adalah bangsa yang plural atau majemuk dengan keragaman suku, agama, dan budaya". Mengingat karakteristik bangsa Indonesia yang majemuk diperlukan suatu sikap yang dapat mengakomodasi perbedaan sehingga dapat mencakup semua golongan. Wajib adanya sikap toleransi, saling menghormati serta hidup saling berdampingan (koeksistensi) antar golongan dan budaya demi tercapainya kehidupan yang harmonis dan damai. Hefner (Budimansyah dan
Suryadi, 2008, hlm.28) "mengilustrasikan Indonesia memiliki warisan dan tantangan pluralisme budaya (cultural pluralism) secara lebih mencolok sehingga dipandang sebagai "lokus klasik" bagi bentukan baru "masyarakat majemuk" (plural society)". Selanjutnya Nasikun (Budimansyah dan Suryadi, 2008 hlm.28) mengungkapkan "bahwa kemajemukan masyarakat Indonesia paling tidak dapat dilihat dari dua cirinya yang unik, pertama secara horizontal ia ditandai oleh kenyataan adanya kesatuan-kesatuan sosial berdasarkan perbedaan suku bangsa, agama, adat, serta perbedaan kedaerahan, dan kedua secara vertikal ditandai oleh adanya perbedaan-perbedaan vertikal antara lapisan atas dan lapisan bawah yang cukup tajam".

Karakteristik kemajemukan masyarakat Indonesia dapat kita pandang dalam dua sudut pandang yaitu dalam sisi kekayaan dan di sisi lain sebagai tantangan timbulnya permasalahan dampak dari perbedaan. Sebagai sebuah khazanah kekayaan bangsa, kemajemukan bangsa Indonesia menjadi sebuah kekuatan bagi Indonesia dalam menjalani pergaulan global yang berdampak pada tidak mudahnya bangsa Indonesia dalam menerima perubahan budaya. Namun sisi lain yang tidak bisa kita lupakan terletak pada peluang terjadinya konflik horizontal antar budaya yang hidup di Indonesia. Soebadio (Ruyadi dalam Wilodati, $2010 \mathrm{hlm} .157$ 158) memberikan gambaran kemajemukan masyarakat Indonesia sebagai sebuah potensi dan sekaligus sebagai permasalahan sebagai berikut.

(1) Indonesia berupa kepulauan yang luas sekali, lebih dari $5.000 \mathrm{~km}$ dari ujung Barat keujung Timur dan hampir $2.000 \mathrm{~km}$ dari ujung Utara keujung Selatan. Hal itu kita ketahui semua. Namun, di setiap daerah, pulau atau di dalam perbatasan suatu suku bangsa, halaman itu tidak selalu disadari. Memang kebanyakan orang tampak sulit sekali membayangkan betapa luasnya Negara Indonesia ini yang dengan politik Wawasan Nusantara sekarang meliputi wilayah 5 juta $\mathrm{km}^{2}$ secara sah.

(2) Dalam wilayah seluas itu, jumlah pulaunya 13.977 walau hanya sekitar 6.000 yang dihuni. Penduduk dalam pulau-pulau itu beranekaragam, berbahasa lebih dari 300 dialek, malahan di antaranya ada bahasa mandiri, sedangkan adat istiadatnya atau budaya setempatnya beraneka variasi pula. 
Hal itupun diketahui umum. Namun, dalam hal ini juga tidak disadari oleh setiap kelompok atau individu secara perorangan.

(3) Keanekaragaman bahasa dan kebudayaan setempat itu akhirnya memiliki dasar yang sama, dalam arti berasal dari rumpun bahasa dan jenis budaya yang sama. Hal itu ditemukan dalam penelitian sosial budaya yang secara mendalam dimulai oleh sarjanasarjana asing pada abad ke-19. Masalah dasar bahasa dan budaya yang sama itupun kita ketahui secara umum sejak cukup lama. Tetapi, sekali lagi, hal itu juga tidak selamanya disadari sepenuhnya oleh kita. Seperti juga lambang negara, Bhineka Tunggal Ika, yang mencerminkan kesadaran akan keanekaragaman dengan dasar yang sama itu dan yang terpampang dimanamana, akhirnya juga tidak setiap waktu diperdalami maknanya, apalagi dijadikan patokan hidup.

Sejalan dengan pendapat di atas Manan dan Ju Lan (2011, hlm.2) mengungkapkan bahwa "kemiskinan, korupsi, lemahnya ketahanan budaya, dan juga konflik antaretnik dan konflik yang mengatasnamakan agama yang marak sejak era reformasi merupakan tantangan yang secara langsung atau tidak langsung memengaruhi kadar nasionalisme Indonesia di kalangan rakyatnya". Latar belakang budaya bangsa yang beraneka ragam memunculkan kecenderungan konflik yang melanda bangsa lebih besar dilatarbelakangi oleh rendahnya kesadaran budaya bangsa sehingga penyelesaian konflik pun harus didasarkan pada pendekatan budaya.

Berangkat dari pandangan tersebut, peluang konflik akan menjadi momok bagi bangsa yang besar ini. Perlu adanya sikap preventif untuk setidaknya mencegah konflik ini terjadi di kemudian hari. Oleh karena itu, langkah yang harus dilakukan bangsa ini adalah melakukan edukasi yang komprehensif dan kontinu dari pada setiap golongan terlebih pada mahasiswa sebagai kalangan pemuda yang cenderung lupa akan budaya bangsa dan semakin rentan tergerus jati dirinya. Hal ini didasarkan pada peran pemuda seperti yang dimuat dalam UU RI No. 40 tahun 2009 tentang Kepemudaan yang berbunyi pemuda berperan aktif sebagai kekuatan moral, kontrol sosial, dan agen perubahan dalam segala aspek pembangunan nasional. Begitu pun didasari atas karakteristik pemuda seperti pada UU RI No. 40 tahun 2009 tentang kepemudaan pasal 6 yaitu "memiliki semangat kejuangan, kesukarelaan, tanggung jawab, dan ksatria, serta memiliki sifat kritis, idealis, inovatif, progresif, dinamis, reformis, dan futuristik".

Mengingat pemuda sebagai ujung tombak perjuangan bangsa, maka sudah selayaknya generasi muda dipersiapkan menjadi pemuda yang mampu menjalankan perannya sesuai amanat konstitusi kepemudaan. Windari (2013, hlm. 10-11) berpendapat:

"Sikap kritis, idealis, inovatif, solider, dan semangat juang tinggi merupakan potensi yang dimiliki pemuda. Sehingga dengan adanya organisasi pemuda, sikap positif ini akan mendorong kegiatan positif untuk nantinya akan mampu menciptakan generasi penerus bangsa yang memegang jabatan tinggi menggantikan pemimpin lama ataupun seniornya."

Permasalahan konflik budaya dan rendahnya kesadaran generasi milenial terhadap implementasi jati diri bangsa saat ini menuntut perlu adanya upaya edukatif sebagai upaya mempersiapkan generasi muda yang memiki karakter kepemimpinan lintas budaya yang memiliki kemampuan komunikasi antarbudaya. Sitaram (Budimansyah dan Suryadi, 2008, hlm. 165) mendefinisikan komunikasi antarbudaya sebagai seni untuk memahami dan saling mengerti antara khalayak yang berbeda kebudayaan. Komunikasi antarbudaya menjadi suatu kebutuhan bagi mahasiswa sebagai generasi milenial yang disiapkan untuk menjadi pemimpin yang memiliki kemampuan resolusi konflik. Kepemimpinan inilah yang dimaknai sebagai pemimpin lintas budaya.

\section{Metode}

Metode yang digunakan dalam penelitian adalah menggunakan pendekatan kualitatif dengan metode deskriptif. Penggunaan metode ini didasarkan pada harapan peneliti yang menginginkan data lapangan dari kondisi sumber data dalam keadaan natural, sehingga peneliti dapat menemukan data yang bersifat natural. Melalui pendekatan kualitatif pula diharapkan mendapatkan informasi mendalam dalam upaya pembentukan karakter kepemimpinan lintas budaya mahasiswa Universitas Buana Perjuangan Karawang. Pengumpulan data dalam penelitian ini di lakukan dengan observasi, wawancara dan dokumentasi. Pengolahan data dilakukan melalui tiga tahap, yaitu reduksi data, penyajian dan penarikan kesimpulan . 


\section{Vol. 20 No. 1 Tahun 2020 | Hal. 28 - 37}

\section{Hasil dan pembahasan \\ Manajemen Konflik di Universitas Buana Perjuangan Karawang}

Hasil wawancara dan observasi yang dilakukan dari beberapa informan mahasiswa ketika dihadapkan pada konflik cenderung memilih dua pilihan yaitu menghindari maupun negosiasi. Hal ini senada dengan pandangan Mankunegara (Muspawi, 2014) yang mengatakan strategi penyelesaian konflik melalui a) menghindar, b) mengakomodasi, c) kompetisi, d) negosiasi, dan e) kolaborasi. Memang tidak bisa menyalahkan sistem pendidikan dari kampus ini mengingat tingkat kemapanan pendidikan belum tercapai. Namun peneliti juga menemukan mekanisme penyelesaian konflik yang dilakukan mahasiswa melalui mediasi antar sejawat. Entah dari mana kemampuan tersebut didapatkan oleh beberapa mahasiswa tersebut. Namun, melihat temuan ini peneliti dapat menyimpulkan bahwa pendidikan resolusi konflik pada jenjang pendidikan sebelumnya belum mampu diimplementasikan secara maksimal oleh mahasiswa dalam lingkup kehidupan kampus dan belum didapatkan oleh mahasiswa secara umum pada jenjang pendidikan sebelumnya. Hal ini memberikan penguatan pada asumsi di atas bahwa pendidikan kita belum memiliki instrumen yang jelas dalam kurikulum pendidikan Indonesia. Juga semakin terkikisnya perilaku sosial ke arah individual sebagai dampak dari teknologi menjadi tantangan tersendiri yang harus dihadapi sistem pendidikan kita. Kembali lagi, jika kita ingat kembali potensi konflik horizontal pada bangsa Indonesia secara umum, maka sudah seharusnya pendidikan kita juga menitikberatkan pada pembentukan kompetensi resolusi konflik bagi generasi muda agar mampu mengelola konflik menjadi hal yang positif.

Menyikapi hal demikian, Universitas Buana Perjuangan Karawang melakukan langkah sebagai upaya manajemen konflik melalui orientasi pegawai dan mahasiswa sebagai upaya preventif, pengawasan dan kontrol lembaga melalui sistem pengawas internal (SPI), dan pembentukan pengadilan penyelesaian konflik mahasiswa maupun pegawai. Program orientasi pegawai menjadi langkah awal yang dilakukan lembaga untuk mempertemukan seluruh pegawai agar memiliki keterikatan emosional antar sesama pegawai sehingga dapat meminimalisir terjadi konflik antar pegawai. Harapannya pegawai mampu memberikan contoh keteladanan kepada mahasiswa. Begitu pun sama halnya dengan program orientasi mahasiswa diarahkan sebagai sarana pengenalan mahasiswa dengan asumsi yang sama untuk memperkuat emosi antar mahasiswa.

Dalam sistem pengelolaan kampus, lembaga membentuk sistem pengawas internal (SPI) dan lembaga penyelesaian konflik. SPI bertindak sebagai pengawas segala tindak laku pegawai dan mahasiswa. Lembaga ini menghimpun segala tindak laku civitas akademik termasuk segala tindakan yang menjurus pada terjadinya konflik. Adapun jika ditemukan konflik baik pegawai maupun yang tidak bisa diselesaikan secara mandiri akan dibawa ke lembaga penyelesai konflik atau diistilahkan sebagai pengadilan yang dibentuk oleh program studi Ilmu Hukum. Pada tahap ini, proses mediasi dilakukan bahkan memiliki kewenangan pengambilan keputusan penyelesaian konflik yang kemudian direkomendasikan untuk ditindaklanjuti oleh rektorat. Pada dasarnya, manajemen konflik di lingkungan Universitas Buana Perjuangan Karawang sedang dalam tahap pengembangan, namun melalui program dan lembaga-lembaga tersebut menjadi langkah awal implementasi manajemen konflik dan meminimalisir konflik yang semakin besar jika tidak diselesaikan. Namun, program dan lembaga ini masih belum bisa efektif mengingat banyak pula konflik antar mahasiswa maupun pegawai di luar jangkauannya. Oleh karena itu perlu adanya tindakan yang lebih masif sebagai upaya manajemen konflik yaitu melalui pembelajaran.

\section{Upaya Edukatif Membentuk Karakter} Kepemimpinan Lintas Budaya sebagai Langkah Membangun Kemampuan Resolusi Konflik Mahasiswa

Upaya edukatif dalam pembentukan kompetensi resolusi konflik pada mahasiswa sebagai generasi milenial merupakan langkah penting yang cakupan lebih masif dan komprehensif. Upaya edukatif ini biasa disebut sebagai pendidikan resolusi konflik menjadi kewajiban yang harus diberikan oleh penyelenggara pendidikan baik tingkat sekolah maupun perguruan tinggi selain adanya pelembagaan manajemen konflik. Pasir (2013, hlm. 183) menyebutkan bahwa:

Pendidikan resolusi konflik ini menjadi sangat penting paling tidak untuk tiga hal. Pertama, manusia secara alamiah adalah 
makhluk yang senantiasa belajar dari apa yang ditangkap oleh indra mereka sepanjang hidupnya. Sebut saja: karakter, emosi, kemampuan memecahkan masalah, dan kemampuan mengurai masalah adalah hasil dari belajar atau yang diajarkan. Kedua, pendidikan resolusi konflik adalah medium yang paling memungkinkan untuk belajar resolusi konflik sebagai sebuah keterampilan; memiliki metode yang jelas dan terstruktur serta dapat diaplikasikan. Ketiga, institusi pendidikan adalah salah satu pihak yang memiliki tanggung jawab paling besar dalam membentuk karakter kemanusiaan.

Hal ini memberikan penguatan bahwa pendidikan resolusi konflik menjadi bagian penting dalam dunia pendidikan. Pendidikan kita maknai sebagai upaya membentuk pemahaman konseptual dan kemampuan tindakan peserta didik agar mampu menjadi manusia seutuhnya. Manusia seutuhnya dalam pandangan agama yaitu sebagai khalifah di muka bumi yang menjauhkan kehidupan dari kehancuran dan mencapai kemaslahatan. Begitu pula dalam pandangan budaya, manusia menjadi penjaga martabat dan melestarikan nilai kehidupan. Kedua pandangan ini menjadi dasar pentingnya pendidikan resolusi konflik mengingat segala bentuk konflik yang terjadi akan mengarah pada kerusakan dan mencederai tugas manusia.

Langkah yang ditawarkan sebagai upaya membangun kompetensi resolusi konflik yaitu melalui pembentukan karakter kepemimpinan lintas budaya. Hal ini didasarkan pada fenomena konflik yang mendera bangsa ini kecenderungan lebih besar jika dilatarbelakangi oleh permasalahan budaya. Hal ini menuntut penyelesaian konflik yang mendasarkan pada pendekatan budaya. Permasalahan ini menuntut setiap orang memiliki kemampuan manajerial yang mampu mengedepankan budaya sebagai dasar resolusi konflik. Konstruksi konflik budaya menuntut para generasi muda memiliki karakter kepemimpinan lintas budaya. Akiga dan Lowe (2004, hlm. 2) mendefinisikan kepemimpinan lintas budaya sebagai berikut.

the ability of an individual (the leader) to intentionally and unequally influence and motivate members of a culturally different group toward the achievement of a valued outcome by appealing to the shared knowledge and meaning systems of that culturally different group.
Pentingnya karakater kepemimpinan lintas budaya pada mahasiswa sebagai generasi milenial dibutuhkan agar mampu menyikapi perbedaan kebudayaan bangsa secara lebih dewasa. Karakteristik kepemimpinan lintas budaya memiliki tujuan dalam membentuk mahasiswa menjadi manusia antarbudaya yang mampu bertindak sesuai dengan nilai-nilai budaya. Budimansyah dan Suryadi (2008, hlm. 175) memandang manusia antarbudaya memperlihatkan sikap agak etnosentris dan lebih menghargai perbedaan budaya dengan perasaan dan perilaku yang toleran dan bisa memadukan perbedaan-perbedaan. Karakteristik bangsa yang majemuk cenderung memperlihatkan perilaku etnosentris dan etnonasionalis yang dapat berdampak pada perpecahan.

Pentingnya pendidikan resolusi konflik dihadapkan pada tantangan posisi yang masih sebatas bidden curriculum sehingga belum mengikat dalam seluruh mata pelajaran. Begitupun pada jenjang perguruan tinggi hanya beberapa di antaranya yang menjadikannya sebagai mata kuliah. Hal ini berdampak pada efektivitas pembelajaran dan hasil yang diharapkan. Mengingat pentingnya menghadapi fenomena konflik di Indonesia sudah saatnya perlu adanya pembenahan kurikulum untuk merevitalisasi pendidikan resolusi konflik.

Memang bukan suatu keharusan menjadi mata pelajaran maupun mata kuliah inti, namun perlu adanya komitmen dari para ilmuwan dan akademisi untuk memfokuskan pada pendidikan resolusi konflik ini. Crawford dan Bodine (Pangabean, 2018) menyebutkan bahwa dalam manajemen konflik berbasis sekolah setidaknya ada empat model yaitu kurikulum proses, mediasi, kelas yang damai, dan sekolah yang damai. Model kurikulum proses menitikberatkan pada penyediaan waktu khusus dalam mata pelajaran atau mata kuliah. Model program mediasi memberikan program kepada siswa atau mahasiswa pilihan yang dipersiapkan menjadi mediator dan negosiator. Model kelas yang damai dilakukan melalui pengintegrasian dalam kegiatan atau manajemen kelas seperti kerjasama, peer mediation, maupun kontroversi akademik. Dan model sekolah yang damai memberlakukan program resolusi konflik secara menyeluruh pada warga sekolah atau perguruan tinggi. Setidaknya keempat model ini menjadi pilihan selain adanya pembenahan kurikulum yang menempatkan pendidikan resolusi konflik sebagai indeed curriculum. 


\section{Vol. 20 No. 1 Tahun 2020 | Hal. 28 - 37}

Adapun upaya edukatif yang diselenggarakan Universitas Buana Perjuangan Karawang dalam membentuk karakter kepemimpinan lintas budaya setidaknya ada dua program baik intrakurikuler maupun ekstrakurikuler yang keduanya memiliki kaitan erat dan berkesinambungan yaitu pelatihan kepemimpinan dan model kelas damai yang diintegrasikan dalam mata kuliah Pendidikan Kewarganegaraan dan mata kuliah Jatidiri Bangsa. Model pelatihan kepemimpinan ini terbagi atas dua program yaitu pelatihan yang dilaksanakan secara militer oleh TNI dan latihan kepemimpinan organisasi. Peserta dari program ini diikuti oleh seluruh mahasiswa tingkat awal. Program ini ditujukan untuk membentuk karakter kepemimpinan mahasiswa dan pemahaman tentang kepemimpinan manajamen organisasi. Harapan dari program ini mahasiswa memiliki sikap kepemimpinan yang bercirikan disiplin, berani, dan tangguh serta memiliki kecerdasan emosional dalam lingkungan sosial. Melalui pelatihan kepemimpinan, mahasiswa diharapkan memiliki kemampuan seperti yang diungkap Siagian (2010, hlm. 4) sebagai berikut.

1) Memahami sepenuhnya berbagai faktorfaktor yang merupakan kekuatan bagi organisasi.

2) Mengenali secara tepat berbagai bentuk kelemahan yang terdapat dalam organisasi.

3) Memanfaatkan berbagai peluang yang mungkin timbul.

4) Menghilangkan berbagai bentuk ancaman yang dapat menjadi penghalang bagi keberhasilan organisasi mencapi tujuan dan berbagai sasarannya.

5) Memiliki sifat yang proaktif dan antisipatif terhadap perubahan yang pasti selalu terjadi, baik karena faktorfaktor intern maupun karena tuntutan perkembangan ilmu pengetahuan dan teknologi.

6) Mendorong para bawahan sehingga bekerja dengan tingkat efisiensi, efektifitas, dan produktifitas yang mendorong keberhasilan usaha.

7) Menciptakan cara dan iklim kerja yang mendukung wawasan kebersamaan dalam usaha pencapaian tujuan.

Adapun dalam aspek intrakurikuler, upaya edukatif yang dilakukan yaitu melalui model kelas damai yang terintegrasikan dalam Pendidikan Kewarganegaraan dan Jatidiri Bangsa. Mengikuti kurikulum yang telah ditetapkan oleh Belmawa Dikti, pembentukan kompetensi resolusi konflik diintegrasikan dalam project citizen yang mengangkat permasalahan sosial dan mendiskusikan solusi yang disarankan. Proyek ini memberikan peluang kepada mahasiswa secara berkelompok untuk terjun ke lapangan dan mendalami masalah permasalahan konflik sosial budaya yang ada di tengah masyarakat. Selanjutnya dilakukan penyusunan laporan dan mempresentasikan di depan kelas. Diskusi dilakukan untuk mencari solusi alternatif yang dapat diterapkan pada permasalahan masyarakat tersebut. Rivai dan Mulyana (2013, hlm. 280) menggambarkan dikotomi tentang konflik seperti berikut.

Tabel 1 Cara Memilih Konflik

\begin{tabular}{|c|c|}
\hline Negatif & Positif \\
\hline Penghamburan tenaga & Permasalahan yang ada \\
Menurunkan semangat kerja & menjadi terbuka dan jelas \\
Memilah-milahkan & Memperbaiki kualitas \\
kelompok dan anggotanya & pemecahan masalah \\
Mempertajam perbedaan & Meningkatkan keterlibatan \\
Merusak kerja sama & para anggota \\
Menimbulkan kecurigaan & Memberikan kesempatan \\
dan ketidakpercayaan & berkomunikasi secara \\
Mengurangi produktivitas & spontan \\
& Menciptakan pertumbuhan \\
& dan penguatan hubungan \\
& Meningkatkan \\
& produktivitas \\
\hline
\end{tabular}

Sumber: Rivai dan Mulyana. 2013.

Selanjutnya, Rivai dan Mulyana (2013, hlm. 280) menyebutkan akibat kedua cara pandang tersebut, lahirlah dua pandangan tentang konflik yaitu pendapat yang berhaluan tradisional dan pendapat yang berhaluan modern yang masing memiliki argumentasi serta ciri-ciri tersendiri. Pandangan tradisional memandang bahwa konflik merupakan hal yang tidak baik, tidak perlu terjadi, dan harus dipecahkan. Sedangkan pandangan modern memandang konflik merupakan hal yang baik yang tak bisa dihindarkan dan merupakan langkah evaluasi menuju perbaikan dan kemajuan organisasi. Menyikapi realitas konflik ini, generasi muda diharapkan mampu menjadi kalangan yang memiliki pandangan modern terhadap konflik. Tantangan bagi bangsa Indonesia adalah mentransformasikan kesadaran baru kepada suatu identitas baru yang bernama identitas nasional dengan implikasi psikologis yang menyenangkan (Mardiansyah, 2001, Hlm. 307; 
Barni, 2019). Mahasiswa diarahkan memiliki kompetensi resolusi konflik sehingga mampu menjadikannya sebagai upaya memajukan bangsa.

Sedangkan, melalui mata kuliah Jatidiri Bangsa mahasiswa secara berkelompok masingmasing diarahkan untuk mendalami budaya dari setiap provinsi di Indonesia melalui outing class di Taman Mini Indonesia Indah. Setiap kelompok mengunjungi anjungan provinsi sesuai dengan penugasan untuk mendalami seluk beluk budaya provinsi tersebut. Hasilnya kemudian dipresentasikan di depan kelas dalam bentuk model dan media. Melalui program ini, mahasiswa dituntut memiliki kecerdasan budaya agar menjadi sosok yang mampu mengelola konflik. Wibowo (2011, hlm. 357) mengatakan:

Manajer memerlukan knowledge atau pengetahuan tentang budaya dan dasar fundamental interaksi antarbudaya. Hal ini berarti mengetahui apa makna budaya itu, bagaimana budaya bervariasi, dan bagaimana budaya mempengaruhi perilaku. Manajer cerdas budaya perlu mempraktikan mindfullness, sesuatu kemampuan memberikan perhatian dalam cara yang reflektif dan kreatif memberikan isyarat dalam situasi lintas budaya.

Dengan adanya pemahaman dan kecerdasan budaya, menjadi bekal bagi mahasiswa-mahasiswa untuk memahami karakteristik budaya yang hidup di masyarakat. Sebagai seorang pemimpin yang hidup dalam budaya yang beragam, kecerdasan budaya menjadi keniscayaan yang harus dimiliki. Kecerdasan ini menjadi modal utama dalam menjaga budaya dan penyelesaian konflik melalui pendekatan budaya. David C. Thomas dan Kerr Inkson (Wibowo, 2011, hlm. 360-361) mengemukakan bahwa pemimpin cerdas budaya mengetahui dan dapat melakukan hal sebagai berikut.

1) Kepemimpinan untuk sebagian besar berada dalam pikiran follower atau pengikut.

2) Beberapa karakteristik pemimpin yang dicari pengikut adalah mereka yang mempunyai: (a) visi kelompok atau organisasi, (b) kemampuan mengomunikasikan visi kepada orang lain, (c) keterampilan mengorganisasi pengikut mencapai visi. Namun, perilaku yang mengindikasikan karakteristik tersebut berbeda di antara budaya yang berbeda.

3) Dimensi kepemimpinan berorientasi task (tugas) dan relationship (hubungan) muncul di setiap budaya. Namun, perilaku yang mengindikasi berorientasi task daripada relationship adalah spesifik untuk budaya yang berbeda.

4) Beberapa pengikut lebih perlu pemimpin yang mempunyai dimensi sejalan daripada lainnya. Faktor seperti norma organisasi dan tingkat pendidikan pengikut dapat bertindak sebagai pengganti kepemimpinan.

5) Berusaha meniru perilaku pemimpin pada budaya pengikut adalah seperti pedang bermata dua. Beberapa adopsi perilaku ini akan mendapatkan penerimaan pemimpin oleh pengikut, tetapi terlalu banyak dapat diinterpretasikan sebagai tidak tulus atau bahkan bersifat menyakitkan.

Pemimpin yang memiliki kecerdasan budaya tidak memaksakan budaya pada kebudayaan lain. Dalam artian mampu menempatkan diri pada kondisi budaya tertentu dalam mengambil sikap. Begitu pula, keragaman budaya dijadikan suatu kekuatan dalam membangun organisasi. Adapun Luthans (Puspitasari, dkk. 2014, hlm. 3) mengungkapkan "tiga faktor yang mempengaruhi kepemimpinan lintas budaya, yaitu nilai-nilai pribadi, latar belakang pemimpin dan kemampuan interpersonal". Nilai pribadi berkaitan dengan karakter yang dimiliki pemimpin dalam mengambil sikap. Hal ini ditenggarai oleh latar belakang pendidikan yang dijalani pemimpin sehingga memiliki kemampuan interpersonal dalam memimpin budaya yang berbeda. Hal ini menjadi penting bagi seorang pemimpin, dengan memahami budaya berdampak pada pengambilan keputusan yang bijak pula.

Hal terpenting dari ketiga program di atas adalah kontinuitas program yang membentuk pemahaman mahasiswa tentang kepemimpinan dan budaya serta konflik dalam masyarakat. Kolaborasi program inilah yang diarahkan untuk membentuk karakter kepemimpinan lintas budaya dimana mahasiswa telah menjalani program latihan kepemimpinan, pemahaman konflik, dan budaya. Perlu disampaikan bahwa seluruh program ini termasuk kategori wajib diikuti dengan konsekuensi mengulang jika tidak lulus melalui program-program tersebut. Melalui 


\section{Vol. 20 No. 1 Tahun 2020 | Hal. 28 - 37}

program-program tersebut, baik disadari maupun tidak, merupakan proses pembentukan karakter kepemimpinan lintas budaya dengan harapan mahasiswa mampu memahami fenomena konflik serta mampu mengelola konflik. Dengan terbentuknya karakter kepemimpinan lintas budaya, mahasiswa diharapkan mampu menjadi sosok sentral dalam pemecahan berbagai konflik di tengah masyarakatnya. Lumbanraja (2018. Hlm. 73) menyebutkan terdapat tiga tipe manajer jika dihubungkan dengan kondisi suatu budaya, yaitu:

- Manajer dalam monoactive culture akan memperlihatkan dan mengutamakan kemampuan teknis, senantiasa berdasarkan fakta dan logika dan tidak berdasarkan perasaan dan emosi.

- Manajer dalam polyactive culture jauh lebih terbuka, mendasarkan pada kemampuan persuasif, menggunakan kekuatan karakter mereka sebagai insentif. Mereka sering menunjukkan komunikasi secara terbuka dengan orang dan mau memberikan waktunya kepada para bawahan mereka untuk mengembangkan hubungan yang lebih baik.

- Manajer dalam reactive culture juga berorientasi kepada bawahan, tetapi mereka mengelola dengan mempergunakan peralatan ilmu pengetahuan, sabar dan menggunakan sistem pengawasan yang tenang.

Untuk itu, mahasiswa sebagai pemimpin lintas budaya juga perlu mengembangkan cultural intelligence $(C Q)$ dengan baik, yang terdiri dari 4 aspek yakni metacognitive (kesadaran), cognitive (pengetahuan), motivational (motivasi), dan behavioral (perilaku). Keempat aspek tersebut diasah secara mandiri dan sangat bermanfaat dalam menciptakan kenyamanan bekerja dalam kondisi kebudayaan yang berbeda (Subroto dan Mas'ud, $2016 \mathrm{hlm}$. 10). Melalui pemahaman budaya, mahasiswa sudah dipastikan memiliki kemampuan komunikasi lintas budaya seperti diungkap Sitaram (Budimansyah dan Suryadi, 2008, hlm. 165) yang mendefinisikan komunikasi antarbudaya sebagai seni untuk memahami dan saling mengerti antara khalayak yang berbeda kebudayaan. Begitu pula Samovar, dkk. (2010, hlm. 13) menyebutkan:

"Komunikasi antarbudaya terjadi ketika anggota dari satu budaya tertentu memberikan pesan kepada anggota dari budaya yang lain. Lebih tepatnya, komunikasi antarbudaya melibatkan interaksi antara orang-orang yang persepsi budaya dan sistem simbolnya cukup berbeda dalam suatu komunikasi."

Komunikasi antarbudaya menjadi jembatan penghubung demi terciptanya keseimbangan dalam kehidupan bernegara. Hal ini dilatarbelakangi oleh perbedaan persepsi budaya yang biasanya menjadi salah satu penyebab terjadinya konflik dalam organisasi. Persepsi warga negara dipastikan berbeda-beda bergantung pada pengalaman dan visualisasi setiap warga negara. Begitu pula budaya sangat mempengaruhi persepsi budaya pada setiap warga negara. Mulyana dan Rakhmat (2010, hlm. 24) berkeyakinan bahwa "komunikasi antarbudaya akan lebih dapat dipahami sebagai perbedaan dalam mempersepsi objek-objek sosial dan kejadian-kejadian". Akiga dan Lowe (2004, hlm. 2) mengungkapkan bahwa hal yang membedakan kepemimpinan lintas budaya dengan kepemimpinan tradisional terletak pada perbedaan budaya yang dihadapi, serta mempertimbangkan perbedaan budaya yang ada dalam proses kepemimpinan.

Melalui upaya edukatif mahasiswa mampu menjadi pemimpin lintas budaya yang diharapkan mampu meminimalisisr peluang konflik yang bisa terjadi pada bangsa Indonesia. Dinamika sosial budaya Indonesia tidak akan terlepas dari konflik yang terus menghantuinya. Konflik horizontal pada dasarnya merupakan suatu yang tidak dihilangkan dari lingkungan yang beragam, namun bukan berarti konflik ini selamanya akan berdampak negatif. Dalam pandangan Malisi (2014, hlm. 54) keragaman budaya yang seringkali menimbulkan kekacauan, apabila dikelola dengan baik dan didukung oleh kepemimpinan yang tepat, akan menjadi sebuah kekuatan. Pada dasarnya konflik adalah sifat alamiah yang pasti sering terjadi. Hal tersebut mendorong perlunya manajemen konflik yang mampu mengambil sisi positif konflik. Dalam kehidupan bermasyarakat dan berbangsa terdapat kecenderungan bahwa masyarakat Indonesia telah terkotak-kotak dalam berbagai kepentingan baik etnik, agama, ideologi, maupun kelompok. Kondisi tersebut sangat mempengaruhi bahkan menghambat proses integrasi dan pembangunan nasional (Lemhannas, 2012, Hlm. 110). Pemimpin lintas 
budaya diharapkan mampu mengelola konflik dan berperan aktif dalam meminimalisir konflik yang pasti terjadi di Indonesia. Kompetensi komunikasi lintas budaya dalam aspek sensitivitas budaya tergambar dari keterbukaan dan relaksasi sosial, kesadaran tinggi pada budaya sendiri dan identitas budaya pihak lain (Elizabeth, hlm. 102).

\section{Simpulan}

Mahasiswa merupakan bagian generasi milenial yang tidak lepas dari tantangan globalisasi. Dampak globalisasi tidak serta membawa dampak positif namun juga berdampak pada terbukanya peluang konflik budaya pada masyarakat Indonesia yang majemuk. Perlu adanya upaya membentuk karakter kepemimpinan lintas budaya pada mahasiswa dalam membangun kemampuan resolusi konflik demi menjawab permasalahan konflik yang mendera bangsa Indonesia. Adapun upaya yang dilakukan Universitas Buana Perjuangan Karawang dalam membentuk karakter kepemimpinan lintas budaya dan kemampuan resolusi konflik melalui upaya pelembagaan dan upaya edukatif. Kedua upaya tersebut saling keterkaitan yang berkesinambungan dalam memaksimalkan perannya membentuk karakter kepemimpinan lintas budaya dan kemampuan resolusi konflik mahasiswa. Perlu adanya pengembangan yang lebih lanjut dari kedua program tersebut baik memaksimalkan peran lembaga maupun pengembangan kapasitas pendidik untuk terus menjawab tantangan zaman mengingat perkembangan zaman yang semakin pesat dan dinamis.

\section{Referensi}

Akiga, dan Kevin B. Lowe. (2004). Encyclopedia of Leadership: Cross-Cultural Leadership. SAGE Reference Online.

Banks, J. A. (2004). Introduction: Democratic citizenship education in multicultural societies. In J. A. Banks (Ed.), Diversity and citizenship education: Global perspectives (pp. 17-48). San Francisco, CA: Jossey-Bass.

Barbules, N. C., \& Torres, C. A. (2000). Globalization and education: An introduction. In N. C. Barbules \& C. A. Torres (Eds.), Globalization and Education: Critical Perspectives (pp. 1-27). New York, NY: Routledge.
Barni, M. (2019). Tantangan Pendidikan di Era Milenial. Jurnal Transformatif, 3 (1). Hlm. 99 116

Budimansyah, D. \& Suryadi, K. (2008). PKn dan Masyarakat Multikultural. Bandung: Prodi PKn SPs UPI.

Castle, S. (2004). Migration, citizenship, and education. In J. A. Banks (Ed.), Diversity and citizenship education: Global perspectives. San Francisco, CA: Jossey-Bass.

Elizabeth, M. (2012). Kompetensi komunikasi lintas budaya dalam aspek sensitivitas budaya tergambar dari keterbukaan dan relaksasi sosial, kesadaran tinggi pada budaya sendiri dan identitas budaya pihak lain. Universitas Indonesia. Tesis: Tidak diterbitkan.

Heater, D. (2000). Does cosmopolitan thinking have a future? Review of International Studies, 26(5), 79-197. https://doi.org/10.1017/S0260210500001 790

Lan, T. J. dan Manan, M. A. (eds). (2011). Nasionalisme dan Ketahanan Budaya di Indonesia: Sebuah Tantangan. Jakarta: Obor Indonesia.

Lemhannas. (2012). Memperkokoh Nilai-Nilai Pancasila. Jurnal Kajian Lembannas RI Edisi 14. Hlm. 97-121.

Lumbanraja, P. (2008). Tantangan Bagi Kepemimpinan Lintas Budaya. Jurnal Manajemen Bisnis. 1 (2). Hlm. 69 - 77

Malisi, A. S. (2014). Kepemimpinan Pendidikan Perspektif Lintas Budaya. Jurnal Kepemimpinan Pendidikan Islam Multikultural. 2 (2). Hlm.2014.

Mardiansyah, A. (2001). Negara Bangsa dan Konflik Etnis: Nasionalisme vs EtnoNasionalisme. Jurnal Ilmu Sosial dan Ilmu Politik. 4 (3). Hlm. 289-316).

Morais, D. B., \& Ogden, A. C. (2011). Initial development and validation of the global citizenship scale. Journal of Studies in International Education, 15(5), 445-466. https://doi.org/10.1177/10283153103753 08

Mulyana, D. \& Rakhmat, J. (2010). Komunikasi Antarbudaya Panduan Berkomunikasi dengan Orang-Orang Berbeda Budaya. Bandung. Remaja Rosdakarya.

Muspawi, M. (2014). Manajemen Konflik (Upaya Penyelesaian Konflik dalam Organisasi). Jurnal Penelitian Universitas Jambi Seri Humaniora. 16 (2). Hlm. 41-46.

Oxfam. (2006). Education for global citizenship: $A$ guide for schools. Oxfam GB. 


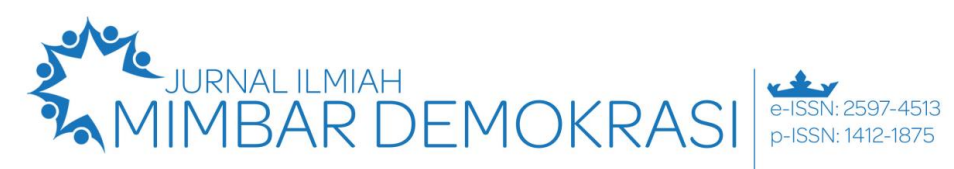

\section{Vol. 20 No. 1 Tahun 2020 | Hal. 28 - 37}

Pangabean, R. (2018). Institusionalisasi Manajemen Konflik Berbasi sekolah. Sukma Jurnal Pendidik. 1 (1). Hlm. 197-218

Pasir, S. (2013). Pendidikan Resolusi Konflik Berbasis Al-Qur'an. Jurnal Pendidikan Islam. 7 (2). Hlm. 181-210

Puspitasari, I. Dkk. (2014). Analisis Gaya kepemimpinan lintas budaya ekspatriat (studi penelitian pada PT. Haier Sales Indonesia Jakarta Utara). Jumal Administrasi Bisnis (JAB). 8 (1). Hlm. 1 - 10.

Rapoport, A. (2010). We cannot teach what we don't know: Indiana teachers talk about global citizenship education. Education, Citizenship and Social Justice, 5(3), 179-190. https://doi.org/10.1177/17461979103822 56

Rivai, V. \& Mulyana, D. (2013). Kepemimpinan dan Perilaku Organisasi. Jakarta: Rajawali Pers.

Samovar, L. dkk. (2010). Komunikasi Lintas Budaya (Communication Between Culture). Jakarta: Salemba Humanika.

Siagian, S. (2010). Teori \& Praktek Kepemimpinan. Jakarta: Rineka Cipta.

Subroto, S. dan Mas'ud, F. (2016). Peran Cultural Intelligence (Cq) Dalam Kepemimpinan Lintas Budaya. Diponegoro Journal of Management. 5 (4). Hlm. 1-12

Undang-Undang Republik Indonesia Nomor 40 tahun 2009 tentang Kepemudaan

Wibowo. (2011). Budaya Organisasi Sebuah Kebutuhan untuk Meningkatkan Kinerja Jangka Panjang. Jakarta: PT Raja Grafindo Persada

Wilodati. (2010). Unity and National Harmony dalam Bingkai Bhineka Tunggal Ika. Jurnal Sekretariat Negara RI No. 16. Hlm. 150-173.

Windari, G.N. 2013. Organisasi pemuda sebagai wahana kaderisasi pemimpin bangsa yang berjiwa Pancasila. Jurnal Jurusan Pendidikan Kewarganegaraan. 1 (3). Hlm. 1 - 15. 